\title{
PENGARUH MOTIVASI DAN LINGKUNGAN KERJA FISIK TERHADAP KINERJA KARYAWAN DENGAN KEPUASAN KERJA SEBAGAI VARIABEL INTERVENING PADA PT AJS
}

\author{
Nurmin Arianto ${ }^{*}$, Ria Septiani ${ }^{2}$ \\ Fakultas Ekonomi, Universitas Pamulang \\ dosen0118@unpam.ac.id1, septianiria084@gmail.com
}

\begin{abstract}
Research purposes. To determine the effect of motivation and physical work environment on employee performance with job satisfaction as an intervening variable. The object of this research is the employees of PT AJS.
\end{abstract}

Research methods. Using associative with the number of respondents 50 people sampling saturated with path analysis method.

Results. From the statistical $t$-test, the motivation variable has a positive and significant effect on performance at PT AJSMuncul, South Tangerang. Likewise, the Physical Work Environment variable has a positive and significant effect on employee performance at PT AJSMuncul, South Tangerang. As for job satisfaction, it does not affect and is not significant on performance at PT AJSMuncul, South Tangerang. Based on the results of this study, it can be seen the direct effect of motivation on performance, and the indirect effect of motivation on performance.

Implications. PT Ajs must foster the motivation that exists in employees by fostering a sense of appreciation and paying attention to the work environment at PT Ajs itself so that employees can produce work as expected so that employees also feel satisfied with the work they are doing.

Keywords. Motivation, Physical Work Environment, Employee Performance, and Job Satisfaction

\begin{abstract}
ABSTRAK
Tujuan Penelitian. Untuk mengetahui Pengaruh Moitivasi dan Lingkungan Kerja Fisik Terhadap Kinerja Karyawan dengan Kepuasan Kerja Sebagai Variabel Intervening. Objek penelitian ini adalah karyawan PT AJS.
\end{abstract}

Metode Penelitian. Menggunakan assosiatif dengan jumlah responden 50 orang sampling jenuh dengan metode analisis jalur.

Hasil. Dari uji t statistik variabel Motivasi berpengaruh positif dan signifikan terhadap kinerja pada PT AJSMuncul, Tangerang Selatan. Begitu juga dengan variabel Lingkungan Kerja Fisik, berpengaruh positif dan signifikan terhadap kinerja karyawan pada PT AJSMuncul, Tangerang Selatan. Adapun Kepuasan Kerja, tidak memiliki pengaruh dan tidak signifikan terhadap kinerja pada PT AJSMuncul, Tangerang Selatan. Berdasarkan hasil penelitian ini dapat diketahui pengaruh langsung motivasi terhadap kinerja dan pengaruh tidak langsung motivasi terhadap kinerja.

Implikasi. PT Ajs harus menumbuhkan motivasi yang ada pada karyawan dengan menumbuhkan rasa penghargaan dan memperhatikan lingkungan kerja yang di PT Ajs sendiri agar karyawan mampu menghasilkan pekerjaan sesuai dengan yang diharpkan sehingga karyawan juga merasa puas terhadap pekerjaan yang dijalaninya.

Kata Kunci. Motivasi, Lingkungan Kerja Fisik, Kinerja Karyawan Dan Kepuasan Kerja 


\section{Pendahuluan}

Motivasi menjadi suatu hal yang sangat penting karena dengan motivasi setiap karyawan akan bekerja keras dan antusias untuk mencapai kinerja yang lebih tinggi. Motivasi seseorang dipengaruhi dan dirangsang oleh keinginan, pemenuhan, kebutuhan serta tujuan dan kepuasan. Rangsangan timbul dari dalam dan luar, hal ini akan menciptakan dorongan pada seseorang untuk melakukan aktivitas. Tanpa adanya motivasi dari perusahaan, maka tujuan yang telah ditetapkan tidak akan tercapai. Sebaliknya, apabila terdapat motivasi yang tinggi dari para karyawan, maka hal ini merupakan suatu jaminan atas keberhasilan perusahaan dalam mencapai tujuannya.

Menurunnya motivasi pada karyawan dapat dibuktikan dengan melibatkan data yang di lihat dari data gaji karyawan perihal dari tahun 2016, 2017 sampai dengan 2018. Dengan adanya bukti data gaji kerja karyawan ini maka dijelaskan bahwa karyawan mengalami kurang motivasi dalam bekerja sehingga turunnya semangat kinerja karyawan itu sendiri. Berikut ini dapat dapat dilihat pada tabel 1 .

Tabel 1. Data Gaji Karyawan PT AJS Tahun 2016 - 2018

\begin{tabular}{|c|c|c|c|c|c|c|c|}
\hline \multirow{2}{*}{ No. } & \multirow{2}{*}{ Jabatan } & \multicolumn{2}{|c|}{ Gaji 2016} & \multicolumn{2}{|c|}{ Gaji 2017} & \multicolumn{2}{|c|}{ Gaji 2018} \\
\hline & & UMR & Real & UMR & Real & UMR & Real \\
\hline 1. & Direktur & Rp.3.021,650,000 & Rp. $2.000,000$ & Rp. $3 \cdot 270,936$ & Rp. $3.000,000$ & Rp.3,555,834 & Rp. $4.000,000$ \\
\hline 2. & Purchasing & Rp.3.021,650,000 & Rp. $2.000,000$ & Rp. $3 \cdot 270,936$ & Rp. $3.000,000$ & Rp.3,555,834 & Rp. $3.800,000$ \\
\hline 3. & Supervisor & Rp.3.021,650,000 & Rp. $1.500,000$ & Rp. $3.270,936$ & Rp. $2.000,000$ & Rp.3,555,834 & Rp. $3.000,000$ \\
\hline 4. & Keuangan & Rp.3.021,650,000 & Rp. $1.500,000$ & Rp. $3 \cdot 270,936$ & Rp. $2.000,000$ & Rp.3,555,834 & Rp. $2.500,000$ \\
\hline 5. & Marketing & Rp.3.021,650,000 & Rp. $1.500,000$ & Rp. $3 \cdot 270,936$ & Rp. $1.700,000$ & Rp.3,555,834 & Rp. $2 \cdot 200,000$ \\
\hline 6. & Op. Gudang & Rp.3.021,650,000 & Rp. $1.500,000$ & Rp. $3 \cdot 270,936$ & Rp. $1.500,000$ & Rp.3,555,834 & Rp. $2.000,000$ \\
\hline 7. & Logistic & Rp.3.021,650,000 & Rp. $1.500,000$ & Rp. $3.270,936$ & Rp. 1500,000 & Rp.3,555,834 & Rp. $2.000,000$ \\
\hline
\end{tabular}

Sumber : Data Gaji Karyawan PT AJS, 2019

Berdasarkan Keterangan Table diatas dapat dijelaskan bahwa PT AJS, dalam memberikan konpensasi terhadap karyawannya masih kurang dari kata cukup (Belum mendapatkan gaji sesuai dengan UMR) dan juga kurangnya pemberian motivasi kepada karyawan, serta tingginya beban kerja yang diberikan perusahaan. Hal inilah yang menyebabkan kurangnya motivasi karyawan dalam bekerja. Untuk dapat memberikan hasil kerja yang berkualitas dan berkuantitas maka seorang karyawan membutuhkan motivasi kerja yang akan berpengaruh terhadap kineja karyawan, selain faktor motivasi kerja lingkungan kerja fisik tempat karyawan bekerja tersebut juga tidak kalah pentingnya dalam meningkatkan kinerja karyawan. Lingkungan kerja yang sesuai dapat menudukung pelaksanaan kerja sehingga sehingga karyawan memiliki semangat kerja dan meningkatkan kinerja karyawan, sedangkan ketidak sesuaian lingkungan kerja dapat menciptakan ketidak nyamanan bagi karyawan dalam melaksanakan tugas-tugasnya.

Lingkungan kerja fisik yang baik dapat mendukung pelaksanaan kerja sehingga karyawan memiliki semangat kerja dan meningkatkan kinerja karyawan. Untuk menciptakan kinerja yang tinggi, dibutuhkan adanya peningkatan kerja yang optimal dan mampu mendayagunkan potensi Sumber Daya Manusia yang dimiliki oleh karyawan guna menciptakan tujuan organisasi, sehingga akan memberikan kontribusi positif bagi perkembangan perusahaan. Lingkungan kerja fisik merupakan salah satu faktor penting yang mempengaruhi hasil kerja manusia. Karena lingkungan kerja berbanding lurus dengan tingkat kenyamanan. Berikut dapat di lihat dari tabel 2 hasil penelitian lingkungan kerja karyawan PT AJS:

Tabel 2. Data Lingkungan Kerja PT AJS

\begin{tabular}{|c|l|c|c|}
\hline No. & \multicolumn{1}{|c|}{ Keterangan } & Expektasi & Realita \\
\hline 1. & Pencahayaan & Terang & Redup \\
\hline 2. & Sirkulasi Udara & Dingin & Panas \\
\hline 3. & Tingkat Kebisingan & Tenang & Bising \\
\hline 4. & Keamanan & Aman & Tidak Aman \\
\hline
\end{tabular}

Sumber : Karyawan PT AJS, 2019 
Rendahnya penerangan ditempat kerja di PT AJS. Menggangu penglihatan karyawan yang sedang bekerja, dan para karyawan sering mengeluh dikarnakan kondisi suhu udara yang lembab dan sangat panas ditambah pula suara bising di ruangan kerja yang mempengaruhi ketidak nyamanan disaat bekerja dan berkurangnya konsentrasi saat bekerja, serta keamanana yang belum memadai dikarnkaan hal inilah salah satu faktor yang sangat mempengaruhi baik dan tidaknya kinerja seseorang adalah lingkungan kerja. Kinerja merupakan hasil kerja secara kualitas dan kuantitas yang dicapai seorang karyawan dalam melaksanakan tugasnya sesuai tanggung jawab yang diberikan kepadanya. Pengertian kinerja itu sendiri adalah gambaran mengenai tingkat pencapaian pelaksanaan suatu program kegiatan atau kebijakan dalam mewujudkan sasaran, visi dan misi perusahaan yang digunakan melalui perencanaan strategi suatu perusahaan. Pada kenyataanya di perusahaan PT AJS masih terdapat beberapa karyawan yang tidak bekerja sesuai standar yang telah di tetapkan oleh perusahaan, dikarnakan kurangnya dorongan dan sasaran pada kinerja karyawan itu sendiri dan umpan balik dari karyawan itu dengan perusahaan PT AJS sehingga kinerja karyawan menurun terdapat karyawan yang masih tidak sesuai dengan harapan perusahaan. Berdasarkan pengamatan dilapangan terdapat permasalahan-permasalahan di anataranya kinerja karyawan pada perusahaan PT AJS, hal ini dapat dilihat dari data penjualan. Berikut dapat dilihat pada tabel 3 dari hasil penelitian kinerja karyawan PT AJS Sebagai Berikut :

Tabel 3. Omset Penjualan Karyawan PT AJS Tahun 2016-2018

\begin{tabular}{|c|c|c|c|c|}
\hline Tahun & Target Pertahun & Pencapaian & Selisih & $\begin{array}{c}\text { Pencapaian } \\
\text { \% }\end{array}$ \\
\hline 2016 & Rp.10.800,000,000,- & Rp.8.126,000,000,- & $(\mathrm{RP} .2 .674,000,000)$ & $80 \%$ \\
\hline 2017 & Rp.10.800,000,000,- & Rp.6,766,800,000,- & $(\mathrm{Rp} .4 .033,200,000)$ & $60 \%$ \\
\hline 2018 & Rp.10.800,000,000,- & Rp.8.344.321.551,- & $(\mathrm{Rp} .2 .455,678,449)$ & $80 \%$ \\
\hline
\end{tabular}

Sumber : Marketing PT AJS 2019

Berdasarkan tabel diatas pada tahun 2016, 2017 sampai dengan 2018 dapat disimpulkan bahwa kinerja di PT AJS belum optimal, dikarenakan pencapain yang selalu tidak mencapai titik target. selain itu PT AJS dalam menentukan target belum sesuai dengan target perusahaan yang berikan kepada karyawan, sehingga umpan balik dari karyawan tersebut masih kurang untuk memberikan lebih pada perusahaan. Kepuasan kerja tidak bisa dilepaskan dari kenyataan bahwa kepuasan kerja karyawan dapat dicapai apabila semua harapannya dapat dipenuhi dalam melaksanakan tugas pekerjaanya. Kepuasan kerja merupakan hal yang sangat penting yang harus di perhatikan. Kepuasan kerja akan tercapai bila kebutuhan karyawan terpenuhi melalui pekerjaan. Dimana kepuasan kerja merupakan keadaan emosi yang senang atau positif. Dengan kepuasan kerja yang tinggi akan meningkatkan kinerja karyawan terhadap organisasi. Kepusan kerja karyawan tersebut dapat di lihat berdasarkan dari data tabel yang ada diantaranya:

Jika di lihat pada (Table 1) Motivasi yang di berikan belum dapat memberikan kepuasan kerja bagi karyawan dimana dalam pemberian konpensasi terhadap karyawan masih kurang dari kata cukup ( Belum mendapatkan gaji sesuai UMR) dan (Table 2) Lingkungan kerja fisik juga tidak memberikan kepuasan kerja bagi karyawan dimana karyawan sering mengeluh di karnakan kondisi suhu udara yang lembab dan sangat panas, di tambah pula suara bising di ruangan kerja yang mempengaruhi ketidak nyamanan di saat bekerja sehingga mengganngu konsentrasi karyawan, serta keamanannya yang belum memadai. Berdasarkan data dari (Table 3) dapat dilihat dari kinerja karyawan dari tahun 2016, 2017 dan 2018 dapat di simpulkan bahwa kinerja di PT AJS belum optimal di karnakan pencapaian yang tidak mencapai titik target. Dikarnakan kurangnya dorongan dan sasaran pada kinerja karyawan sehingga tidak adanya umpan balik dari karyawan itu sendiri dikarnakan tidak adanya kepuasan kerja yang di terima karyawan tersebut. Dari latar belakang yang dikemukakan, maka didalam kesmpatan ini peneliti tertarik untuk melakukan penelitian tentang "Pengaruh Motivasi dan Lingkungan Kerja Fisik Terhadap Kinerja Karyawan dengan Kepuasan Kerja Sebagai Variabel Intervening Pada PT AJS. 


\section{Kajian Pustaka dan Hipotesis}

Motivasi. Motivasi adalah faktor yang mendorong seseorang melakukan suatu aktivitas tertentu, oleh karena itu motivasi sering diartikan sebagai faktor pendorong prilaku seseorang, Sutrisno (2010:109). Disisi lain Samsudin (2010:281), mengemukakan bahwa motivasi adalah proses mempengaruhi atau mendorong dari luar terhadap seseorang atau kelompok kerja agar mereka mau melaksanakan sesuatu yang telah di tetapkan. Sedangkan Winardi (2016:6), mengemukakan bahwa motivasi merupakan suatu kekuatan potensial yang ada dalam diri seorang manusia, yang dapat dikembangkan sendiri atau di kembangkan oleh sejumlah kekuatan luar yang pada intinya berkisar sekitar imbalan moneter dan imbalan non moneter, yang dapat mempengaruhi hasil kinerjanya secara positif atau negatif.

Berdasarkan uraian pendapat dari para ahli diatas, dapat disimpulkn bahwa motivasi adalah dorong atau perangsang yang membuat seseorang melakukan pekerjaan yang diinginkan dengan rela tanpa merasa terpakasa sehingga pekerjaan yang di lakukan dapat berjalan dengan baik atau menghasilkan sesuatu yang memuaskan. Sedangkan indikator yang digunakan untuk mengukur motivasi tersebut menurut Sutrisno (2010:109) ialah Kebutuhan Fisiologis, Kebutuhan rasa aman, Kebutuhuan sosial dan rasa ingin memiliki, Kebutuhan harga diri, Kebutuhan aktualisai diri.

Lingkungan Kerja Fisik. Lingkungan kerja fisik dapat di artikan semua keadaan yang ada di sekitar lingkungan kerja yang dapat mempengaruhi kinerja karyawan. Menurut Sedarmayanti (2013:22), yang di maksud lingkungan kerja fisik adalah kondisi semua keadaan berbentuk fisik yang terdapat di sekitar tempat kerja dimana dapat mempengaruhi kerja karyawan baik secara langsung maupun tidak lansgung. Menurut Mangkunegara (2011:105), Lingkugan kerja fisik merupakan salah satu faktor yang mempengaruhi kinerja karyawan. Seorang karyawan yang bekerja dilingkungan kerja fisik yang baik dan mendukung untuk bekerja secara optimal akan menghasilkan kinerja yang baik pula, sebaliknya apabila seorang karyawan karyawan bekerja di lingkkungan kerja fisik yang tidak mendukung atau kurang memadai untuk bekerja secara optimal maka akan membuat menjadi tidak nyaman, cepat lelah, malas sehingga kinerja karyawan tersebut akan rendah.

Berdasarkan uraian di atas maka dapat disimpulkan bahwa lingkungan kerja fisik adalah segala sesuatu yang ada di sekitar tempat kerja karyawan yang dapat terlihat langsung bentuk fisiknya dan juga dapat mempengaruhi sikap dan perilaku karyawan dalam melaksanakan aktivitasnya. Indikato yang digunakan untuk mengukur Lingkungan kerja fisik sendiri menurut Sedarmayanti (2013:23) yaitu Pencahayaan, Sirkulasi Udara, Tingkat Kebisingan, Keamanan.

Kinerja Karyawan. Kinerja merupakan hasil yang dicapai oleh seseorang sesuai dengan ukuran yang berlaku untuk pekerjaan yang bersangkutan, Riani (2013:61). Sedangkan Mangkunegara (2013:67), megatakan bahawa kinerja karyawan adalah kerja secara kualitas dan kuantitas yang dicapai oleh seorang karyawan dalam melaksanakan tugasnya sesuai tanggung jawab yang diberikan kepadanya. Disisilain Wibowo (2011:48), kinerja adalah suatu tanggung jawab setiap individu terhadap pekerjaan, membantu mendefinisikan harapan kinerja, mengusahakan kerangka kerja bagi supervisor dan pekerja saling berkominukasi. Kinerja pada sumbernya merupakan hasil kerja secara menyeluruh tugasnya sesuai tanggung jawab yang diberikan kepada karyawan.

Berdasarkan penjelasan diatas dapat disimpulkan bahwa kinerja adalah hasil kerja yang dilakukan oleh seseorang dalam periode tertentu dalam melaksanakan tugas dan tanggung jawab yang diberikan untuk mencapai sebuah tujuan. Dari yang disampiakan maka indikator yang digunakan untuk mengukur kinerja tersbeut menurut Mangkunegara (2012:9) yaitu Kualitas Kerja, Kuantitas Kerja, Kerja Sama, Tanggung Jawab, Inisiatif.

Kepuasan Kerja. Kepuasan kerja sebagai seperangkat peraturan yang menyangkut tentang perasaan menyenagkan dan tidak menyenangkan berhubungan dengan pekerjaan mereka, Luthans (2011:141). Wirawan (2011:138), kepuasan kerja menurapakan perasaan dan sikap positif atau negatif seseorang terhadap pekerjaanya menyukai dan termotivasi untuk melaksanakan pekerjaanya dan kinerjanya tinggi, sebaliknya jika tidak puas denga 
pekerjaanya ia tidak termotivasi untuk melaksanakan pekerjaanya dan kinerjanya rendah. Sedangkan Hasibuan (2019:202), kepuasan kerja adalah sikap emosional yang menyenagkan dan mencintai pekerjaanya. Sikap ini dicerminkan oleh moral kerja, kedisiplinan, dan prestasi kerja. Kepuasan kerja dinikmati dalam pekerjaan, luar pekerjaan, dan kombinasi dalam dan luar pekerjaan.

Berdasarkan menurut para ahli diatas dapat disimpulkan bahwa kepuasan kerja secara individu adalah jumlah dari kepuasan kerja (dari setiap aspek pekerjaan) dikalikan derajat pentingnya aspek pekerjaan bagi individu. Seseorang individu akan merasa puas atau tidak puas terhadap pekerjaanya merupakan suatu yang bersifat pribadi, yaitu tergantung bagaimana ia mempersiapkan adanya kesesuaian atau pertentangan antara keinginankeinginan dengan hasil keseluruhan yang didapat. Dan dapat di simpulkan pula penegertian kepuasan kerja adalah sikap positif dari tenaga kerja meliputi perasaan dan tingkah laku terhadap pekerjaannya melalui penilaian salah satu pekerjaan sebagai rasa menghargai dalam mencapai salah satu nilai-nilai penting pekerjaan. Indikator yang digunakan mengukur kepuasan kerja Menurut Luthans (2011:141) ialah pekerjaan, Gaji, Promosi, Pengawas, Rekan kerja, Keuntungan Karyawan.

Kerangka Pemikiran. Berdasarkan teori dan penelitian terdahulu yang sudah ada maka dibuatlah sebuah model penelitian di bawah ini:

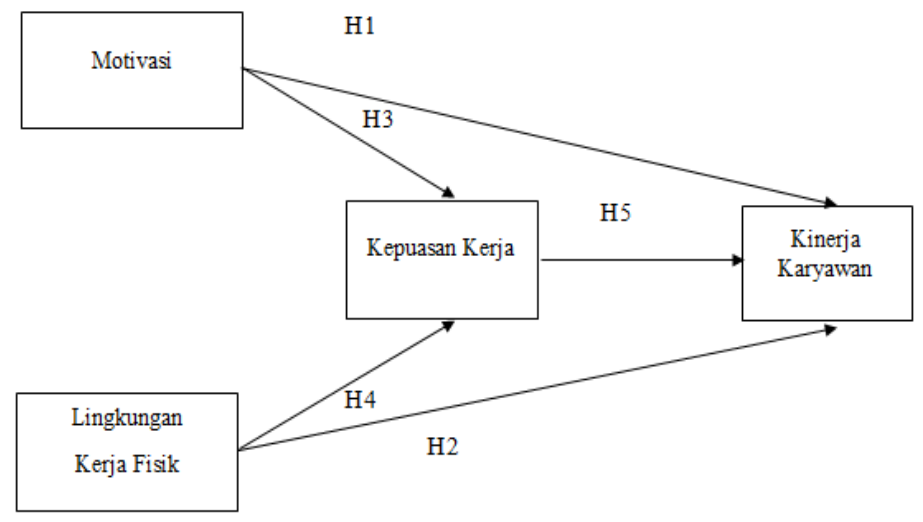

Gambar 1. Model Penelitian

Hipotesis. Jika dilihat dari model penelitian yang sudah ada maka terbentukalan Hipotesis penelitian dimana Sugiyono (2011:64), Hipotesis adalah "Proposi atau dugaan yang menjelaskan suatu fenomena yang belum terbukti kebenaran nya sehingga perlu diuji secara impiris untuk membuktikan kebenarannya". Hipotesis dapat diartikan kesimpulan yang bersifat sementara terhadap permasalahan penelitian sampai terbukti melalui data yang terkumpul. Adapun Hipotesis penelitian ini diduga bahwa ada hubungan anatara kinerja karyawan

$\mathrm{H}_{1} \quad$ : Terdapat pengaruh Motivasi terhadap Kinerja Karyawan PT AJS

$\mathrm{H}_{2}$ : Terdapat pengaruh Lingkungan Kerja Fisik terhadap Kinerja Karyawan PT AJS

$\mathrm{H}_{3}$ : Terdapat pengaruh Motivasi terhadap Kepuasan Kerja PT AJS

$\mathrm{H}_{4} \quad$ : Terdapat pengaruh Lingkungan Kerja Fisik terhadap Kepuasan PT AJS

$\mathrm{H}_{5}$ : Terdapat pengaruh Kepuasan Kerja terhadap Kinerja Karyawan PT AJS

\section{Metode Penelitian}

Sifat Penelitian. Penelitian ini adalah penelitian kuantitatif asosiatif, merupakan penelitian yang mencari hubungan antara dua variabel atau lebih. Tujuan dari penelitian asosiatif adalah untuk mencari hubungan antara satu variabel dengan variabel lain dan untuk mengidentifikasikan sebab akibat antara variabel - variabel yang berfungsi sebagai penyebab dan variabel mana berfungsi sebagai akibat, yang menjadi objek penelitian ini adalah karyawan dari PT AJS yang berada di Tangerang Selatan, sedangkan jumlah populasi dalam 
penelitian ini adalah karyawan yang bekerja priode 2018 yaitu sebanyak 50 karyawan sedangakan sampel yang digunakan dalam penelitian ini menggunakan sample jenuh dimana seluruh anggota populasi yang dijadikan sampel dalam sebuah penelitian.

Metode Pengumpulan Data. Dalam penelitian ini peneliti menggunakan Obervasi Partisipan dimana peneliti ikut serta dalam kegiatan yang akan di observasi, selain itu peneliti juga bekerja pada prusahaan tersebut. Selain itu peneliti menggunakan teknik wawancara tak terstruktur, karena pewawancara menyampaikan beberapa pertanyaan yang sudah disiapkan pewawancara sebelumnya sehingga proses wawancara dapat terarah dengan baik, wawancara ini dilakukan pada saat peneliti ingin memperoleh mengetahui permasalahan yang ada diperusahaan tersebut dan yang terahir peneliti menggunakan penyeberan angket atau kuisioner kepada responden yang menjadi bahan penelitian, adapun kuisioner yang digunakan adalah kuisioner tertutup dimana peneliti sudah menyediakan jawaban dalam kuisioner tersebut sehingga responden dapat memilih jawaban sesuai yang ada dikuisioner tersebut.

Teknik Analsis Data. Analisis data yang dilakukan peneliti yaitu uji Intrumen yang terdiri dari uji validitas, reliabilitas dan uji asumsi klasik. Sedangkan untuk mengetahui besarnya pengaruh setiap variabel peneliti menggunakan analisis jalur dengan bantuan program SPSS.

\section{Hasil Penelitian dan Pembahasan}

\section{Profil Perusahaan}

Perusahaan ini bergerak dalam bidang penjualan bahan kimia. Berbagai bahan kimia kami sediakan baik kimia analisis maupun teknis. Dalam tahun 2018 perusahaan PT AJS ini mengalami kenaikan omset menhalami perkembangan yang sangat baik. Kami melakukan penjualan bahan kimia ke perusahaan-perusahaan besar baik daerah jabodetabek maupun luar kota dan Kami bisa melayani penjualan keseluruh indonesia. PT AJS akan senantiasa berkomitmen untuk mengakomodasikan setiap kebutuhan client. Memperbaiki setiap layanan yang ada sehingga setiap client mendapatkan kepuasan yang maksimal.

\section{Hasil Uji Instrumen}

Uji instrumen yang dilakukan dalam penelitian ini yaitu uji validitas, uji relibilitas dan asumsi klasik yang ada dibawah ini:

Tabel 4. Hasi Uji Valididitas

\begin{tabular}{|c|c|c|c|c|c|c|}
\hline \multirow[b]{2}{*}{ No } & \multicolumn{4}{|c|}{ R hitung } & \multirow[b]{2}{*}{$\mathrm{R}$ tabel } & \multirow[b]{2}{*}{ Keputusan } \\
\hline & $\begin{array}{c}\text { Motivasi } \\
\text { Kerja }\end{array}$ & $\begin{array}{c}\text { Lingkungan } \\
\text { Kerja Fisik }\end{array}$ & Kinerja & $\begin{array}{c}\text { Kepuasan } \\
\text { Kerja }\end{array}$ & & \\
\hline 1 & 0,841 & 0,669 & 0,878 & 0,562 & 0,300 & Valid \\
\hline 2 & 0,773 & 0,586 & 0,880 & 0,445 & 0,300 & Valid \\
\hline 3 & 0,773 & 0,790 & 0,880 & 0,854 & 0,300 & Valid \\
\hline 4 & 0,606 & 0,547 & 0,597 & 0,522 & 0,300 & Valid \\
\hline 5 & 0,943 & 0,305 & 0,880 & 0,387 & 0,300 & Valid \\
\hline 6 & 0,773 & 0,415 & 0,878 & 0,428 & 0,300 & Valid \\
\hline 7 & 0,694 & 0,601 & 0,878 & 0,445 & 0,300 & Valid \\
\hline 8 & 0,942 & 0,520 & 0,878 & 0,579 & 0,300 & Valid \\
\hline 9 & 0,746 & 0,609 & 0,88 & 0,854 & 0,300 & Valid \\
\hline 10 & 0,943 & 0,463 & 0,644 & 0,584 & 0,300 & Valid \\
\hline 11 & & & & 0,854 & 0,300 & Valid \\
\hline 12 & & & & 0,477 & 0,300 & Valid \\
\hline
\end{tabular}

Sumber: Hasil olah data

Jika dilihat dari hasil pengujian instrumen dengan menggunakan uji validitas dimana diperoleh nilai $r$ hitung rata-rata diatas 0,300 hal ini sejalan dengan Teori Sugiyono (2018:126) dimana bila korelasi tiap faktor tersebut positif dan besarnya 0,3 ke atas maka faktor tersebut merupakan contruct yang kuat. 
Tabel 5. Uji Reliabilitas

\begin{tabular}{|c|c|c|c|c|}
\hline No & Variabel & Chronbach Alpha & Standar CA & Kep \\
\hline 1 & Motivasi & 0,927 & \multirow{4}{*}{$\begin{array}{l}0 \\
\stackrel{0}{\circ}\end{array}$} & \multirow{4}{*}{ 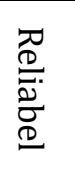 } \\
\hline 2 & Lingkungan Kerja Fisik & 0,733 & & \\
\hline 3 & Kepuasan & 0,949 & & \\
\hline 4 & Kinerja Karyawan & 0,855 & & \\
\hline
\end{tabular}

Sumber: Hasil olah data

Dari hasil olah data maka terlihiat jika nilai cronbach alpha $>0,700$, hal in sejalan dengan teori yang diungkapkan oleh Sugiyono (2018:121) mengemukakan bahwa instrument yang reliabel adalah instrument yang bila digunakan beberapa kali untuk mengukur objek yang sama, akan menghasilkan data yang sama dengan batas nilai yaitu 0,7.

\section{Uji Asumsi Klasik}

Dalam penelitian ini peneliti melakukan uji asumsi klasik sebanyak dua kali karena ada dua persamaan yang harus di uji berdasarkan analisis jalur yang dilakukan.

\section{Uji Normalitas}

Dalam penelitian ini menggunakan Kolmogorov-Smirnov Test dengan syarat significancy $\alpha>0.050$.

Tabel 6. Hasil Uji Normalitas Dengan Kolmogrov-Smirnov Test

\begin{tabular}{|l|c|c|}
\hline & $\begin{array}{c}\text { Unstandardized } \\
\text { Residual Pers.1 }\end{array}$ & $\begin{array}{c}\text { Unstandardized } \\
\text { Residual Pers.2 }\end{array}$ \\
\hline Asymp. Sig. (2-tailed) & 0,200 & 0,200 \\
\hline
\end{tabular}

Sumber: Hasil olah data

Dari data tabel diatas dapat diketahui nilai Sig $\alpha=0,200$ adalah lebih besar dari 0,05 atau $0,200>0,05$, maka asumsi distribusi persamaan pada uji ini adalah nornal.

\section{Uji Multikolinieritas}

Uji ini dapat dilakukan dengan melihat nilai Tolerance Value dan Variance Inflation Factor (VIF).

Tabel7. Hasil Pengujian Multikolonieritas Dengan Collinearity Statistic

\begin{tabular}{|l|c|c|c|c|}
\hline \multirow{2}{*}{ Model } & \multicolumn{2}{|c|}{ Persamaan 1 } & \multicolumn{2}{c|}{ Persamaan 1 } \\
\cline { 2 - 5 } & Tolerance & VIF & Tolerance & VIF \\
\hline Motivasi & 0,914 & 1,094 & 0,916 & 1,091 \\
\hline Lingkungan Kerja Fisik & 0,780 & 1.283 & 0,916 & 1,091 \\
\hline Kepuasan Kerja & 0,847 & 1,180 & & \\
\hline
\end{tabular}

Sumber: Hasil olah data

Berdasarkan hasil pengujian multikolinieritas pada tabel di atas diperoleh nilai tolerance masing-masing variabel bebas lebih dari 0,10, dan nilai Variance Inflation Factor (VIF) kedua variabel < 10,0. Dengan demikian model regresi ini tidak ada multikolinearitas.

\section{Analisis Deskriptif Karaktersitik Responden}

Berdasarkan jenis kelamin yang bekerja di perusahaan ini mayoritas adalah laki-laki sebnayk 37 atau $74 \%$ hal ini dikarenakan sebagian besar barang-barang stok gudang perusahaan tersebut memang cukup banyak dan memerlukan tenaga laki-laki untuk bongkar muartbahan kimia industri tersebut. Sedangkan jika dilihat dari usia karyawan maka mayoritas dalam penelitian ini adalah Usia 20-29 sebanyak 26 atau 52\% hal ini dikarenakan menganggap bahwa mempekerjakan karyawan diusia tersebut lebih mempunyai rasa semangat yang tinggi. Dan dari tingkat pendidikan maka mayoritas karyawan yang bekerja diperusahaan ini adalah pendidikan SMA/K sebanyak 38 atau $76 \%$ hal ini dikarenakan perusahaan ini bergerak di bidang Retail dan disni merupakan karyawan lama semua sehingga 
belum ada standarisasi rekrtmet karyawan dengan tingatkat pendidikan S1, sehingga pada saat itu hanya SMA/K.

\section{Analisis Deskriptif Variabel Motivasi}

Dari hasil penelitian yang dilakukan oleh penulis dimana motivasi yang ada di perusahaan tersebut ternyata sudah Sangat Baik, hal ini diperoleh skor rata-rata yaitu 4,71 berada diantra 4,21-5,00 dan hal ini dibuktikan dengan skor tertinggi pada indikaroe kebutuhan rasa aman yaitu 4,89 hal ini menandakan bahwa setiap karyawan yang berkerja diberikan perlindungan kecelakan kerja serta kantor yang selalu diawasi dengan kamera CC TV sehingga dapat memberikan rasa nyaman pada karyawan yang bekerja. Disamping itu masih terdapat skor rendah yaitu sebesar 4,48 yaitu pada indicator Kebutuhan Harga Diri, hal ini menandakan perusahaan harus dapat meberikan kedudukan kepada karyawan berprestasi atau memberikan penghargaan berupa barang untuk karyawan yang berprestasi, agar karyawan dapat merasa dihargai baik dari dari kerja nya yang dilakukan selama ini.

\section{Analisis Deskriptif Variabel Lingkungan Kerja Fisik}

Dari hasil olah data penyeberan kuisioner maka variabel lingkungan kerja fisiik dikatak sudah baik hal ini dilihat dari skor rata-rata yaitu 3,70 terletak diantara 3,40-4,19 hal ini dibuktikan juda dengan skor tertinggi yaitu 5,72 pada indikator keamanan dimana hal ini menandakan bahwa suasana ditempat bekerja aman dan mampu membuat karyawan merasa nyaman pada saat bekerja hal ini juga memperkuat tanggapan responden tentang motivasi yang mebutuhkan rasa aman yang sudah didapat oleh karyawan. Disamping itu masih terdapat skor rendah yaitu sebesar 3,69 pada indicator Pencahayaan dimana penerangan yang ada di tempat kerja dirasan masih kurang oleh karyawan dan system pencacahayaan yang kurang menyulitkan karyawan menyelesaikan pekerjaan dengan cepat, maka dari itu sebaiknya perusahaan memperbaiki sistemn pecahayaan di tempat bekerja, agar karyawan dapat bekerja dengan baik dan tenang seperti memberikan lampu tambhan atau jendela tambahan sehingga memudahkan cahaya matahari lebih masuk keruang kerja.

\section{Analisis Deskriptif Variabel Kinerja}

Dari hasil penelitian maka kinerja diperoleh skor 4,22 termasuk pada skala 4,21 - 5,00 dengan kriteria sangat baik, dan dibuktikan dari skor tertinggi pada indicator Kuantitas Kerja sebesar 4.38, hal ini menandakan bahwa rata-rata selama bekerja karyawa berrusaha bekerja lebih baik di banding dengan waktu lalu dan kuantitas pekerjaayang diselesaikan sesuai dengan target yang di berikan hal ini membuktikan bahwa karyawan sudah dapat bekerja dengan baik dan memenuhi target perusahaan. Selian itu masih terdapat skor rendah yaitu 4,15 pada indicator kualitas pekerjaan yang di hasilkan hal ini terkadang membuat karyawan yang bekerja tidak sesuai dengan kualitas yang dihasilkan hal ini terkadang disebabkan oleh target perusahaan dalam menyelesaikan pekerjaan sehingga membuat karyawan yang bekerja kurang telit, maka dari itu sebaiknya perusahaan meberikan kelonggaran waktu dalam menyelesaikan target pekerjaan kepada karyawan agar kualitas pekerjaan yang dihasilkan sesuai dengan yang diharapkan.

\section{Analisis Variabel Kepuasan Kerja}

Dari hasil analisis data maka diperoleh skor rata-rata 4,16 terletak diantara skala 4,21 5,00 dengan kriteria sangat baik, dan dibuktikan dari skor tertinggi pada indicator Promosi yaitu sebesar 4,78 hal ini menandakan bahwa promosi yang dilakukan sudah sesuai dengan hasil dan prestasi kerja yang dimiliki oleh karyawan sehingga karyawan dpaat l ebih berkembang dan maju lagi. Namun disampaing itu masih terdapat skor rendah yaitu 3,49 pada indikator gaji, dimana banyak karyawan yang mengeluhakn bahwa gaji yang diterima belum sesuai dengan beban kerja yang mereka jalankan sehingga menyebabkan karyawan kurang puas, maka dari itu sebaiknya perushaan membayara karyawan sesuai dengan beban kerjanya misanya sepereti ada lemburan maka lebih baik di hitung agar menambahkan gaji yang diperoleh karyawan. 
Tabel 8. Hasil Uji T Test Motivasi, Lingkungan kerja Fisik dan Kepuasan Terhadap Kinerja Coefficients ${ }^{\mathbf{a}}$

\begin{tabular}{|l|r|r|r|r|r|}
\hline \multirow{2}{*}{ Model } & \multicolumn{2}{|c|}{$\begin{array}{c}\text { Unstandardized } \\
\text { Coefficients }\end{array}$} & $\begin{array}{c}\text { Standardized } \\
\text { Coefficients }\end{array}$ & \multirow{2}{*}{$\mathrm{t}$} & \multirow{2}{*}{ Sig. } \\
\cline { 2 - 3 } & \multicolumn{1}{|c|}{ B } & Std. Error & Beta & & \\
\hline \multirow{2}{*}{ (Constant) } & 5,433 & 10,8 & & 0,503 & 0,617 \\
Motivasi & 0,337 & 0,166 & 0,274 & $\mathbf{2 , 0 3 3}$ & $\mathbf{0 , 0 4 8}$ \\
Lingkungan Kerja Fisik & 0,493 & 0,22 & 0,326 & $\mathbf{2 , 2 3 7}$ & $\mathbf{0 , 0 3}$ \\
Kepuasan Kerja & 0,015 & 0,155 & 0,014 & $\mathbf{0 , 0 9 9}$ & $\mathbf{0 , 9 2 2}$ \\
\hline
\end{tabular}

a. Dependent Variable: Kinerja

Sumber: Hasil olah data

Berdasarkan tabel diatas dapat disimpulkan bahwa :

1) Motivasi mempunyai nilai t sebsar $\mathbf{2 , 0 3 3}$ dan nilai signifikansi $\mathbf{0 , 0 4 8}<0,05$, hal ini berati bahwa nilai 2,033 > 2,008 dan $\mathbf{0 , 0 4 8}<\mathbf{0 , 0 5}$ yang berati bahwa motivasi memiliki pengaruh yang positif dan signifikan terhadap kinerja.

2) Lingkungan Kerja Fisik mempunyai nilai t sebesar 2,237 dan nilai signifikansi yaitu 0,030 sehingga $2,237>2,008$ dan $0,030<0,05$ yang berarti bahwa Lingkungan Kerja Fisik memiliki pengaruh yang positif dan signifikan terhadap kinerja.

3) Kepuasan memiliki nilai 0,099 dan nilai signifikan 0,922 sehingga 0,099 2,008 dan $0,922>0,05$ maka kepuasan tidak memiliki pengaruh dan tidak signifikan terhadap kinerja.

Tabel 9. Hasil Uji T Test Motivasi, Lingkungan Kerja Fisik - Kepuasan Coefficients ${ }^{\mathbf{a}}$

\begin{tabular}{|c|c|c|c|c|c|}
\hline \multirow[t]{2}{*}{ Model } & \multicolumn{2}{|c|}{$\begin{array}{c}\text { Unstandardized } \\
\text { Coefficients }\end{array}$} & \multirow{2}{*}{$\begin{array}{c}\begin{array}{c}\text { Standardized } \\
\text { Coefficients }\end{array} \\
\text { Beta }\end{array}$} & \multirow[t]{2}{*}{$\mathrm{t}$} & \multirow[t]{2}{*}{ Sig. } \\
\hline & $\mathrm{B}$ & Std. Error & & & \\
\hline (Constant) & 29,354 & 9,247 & & 3,174 & 0,003 \\
\hline Motivasi & $-0,058$ & 0,156 & $-0,052$ & $-0,37$ & 0,713 \\
\hline Lingkungan Kerja Fisik & 0,551 & 0,192 & 0,403 & 2,872 & 0,006 \\
\hline
\end{tabular}

a. Dependent Variable: Kepuasan Kerja

Sumber: Hasil olah data

1) Motivasi mempunyai nila t sebsar $\mathbf{- 0 , 3 7 0}$ dan nilai signifikansi $\mathbf{0 , 7 1 3}>\mathbf{0 , 0 5}$, hal ini berati bahwa nilai $-\mathbf{0 , 3 7 0}<2,008$ dan 0,713 $>0,05$ yang berati bahwa motivasi tidak memiliki pengaruh serta negative dan tida signifikan terhadap kepuasan kerja.

2) Lingkungan Kerja Fisik mempunyai nila t sebesar 2,872 dan nilai signifikansi 0,006 > 0,05, hal ini berati bahwa nilai 2,872 > 2,008 dan 0,006 > 0,05 yang berati bahwa Lingkungan Kerja Fisik memiliki pengaruh yang positif dan signifikan terhadap kepuasan.

\section{Analisis Kuantitatif Uji F}

Tabel 10. Hasil Uji F Test Motivasi, Lingkungan Kerja Fisik-Kepuasan ANOVAa

\begin{tabular}{|l|r|r|r|r|l|}
\hline Model & Sum of Squares & \multicolumn{1}{c|}{ Df } & Mean Square & F & \multicolumn{1}{c|}{ Sig. } \\
\hline Regression & 317,072 & 3 & 105,691 & 4,771 &, $006^{\mathrm{b}}$ \\
1 Residual & 1018,95 & 46 & 22,151 & & \\
Total & 1336,02 & 49 & & & \\
\hline
\end{tabular}

a. Dependent Variable: Kinerja

b. Predictors: (Constant), Kepuasan Kerja , Motivasi , Lingkungan Kerja Fisik Sumber: Hasil olah data 
Adapun penjelasan mengenai hasil uji $\mathrm{F}$ yang telah disajika pada table diatas bahwa nilai $\mathrm{F}$ hitung 4,771 dengan nilai signifikansi 0,006. Hal ini menunjukan bahwa 4,771 > 3,200 dan 0,006 < 0,05 yang arti nya secara simultan variable motivasi, lingkungan kerja fisik dan kepuasan kerja memiliki pengaruh terhadap kinerja secara postif dan signifikan.

\section{Uji Path Analisis}

Untuk menguji pengaruh variable intervening digunakan meotde analisis jalur yang merupakan perluasan dari analisis regresi linier berganda atau analisis jalur adalah penggunaan analisis regresi untuk menaksir hubungan kausalitas antar variable (modecausal) yang telah ditetapkan sebelumnya berdasarkan teori dan menentukan pola hubungan antara tiga atau lebih variable dan tidak dapat digunakan untuk mengkonfirmasi atau menolak hipotesis (Ghazali, 2013:249). Berdasarkan table diatas kemudin menghasilkan model analisis jalur seperti dibawah ini:

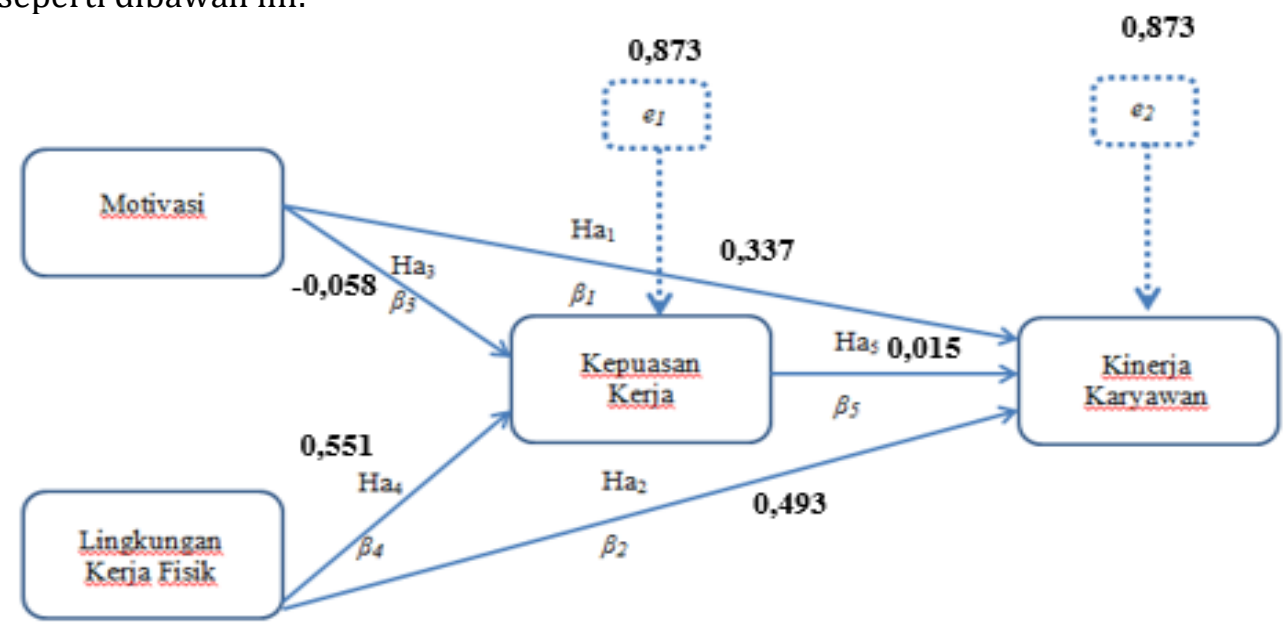

Gambar 2. Konsep Penelitian

Tabel 11. Hasil Uji T test Motivasi, Lingkungan Kerja Fisik, Kepuasan- Kinerja Coefficients ${ }^{\mathbf{a}}$

\begin{tabular}{|c|c|c|c|c|c|c|}
\hline & \multirow[t]{2}{*}{ Model } & \multicolumn{2}{|c|}{$\begin{array}{c}\text { Unstandardized } \\
\text { Coefficients }\end{array}$} & \multirow{2}{*}{$\begin{array}{c}\begin{array}{c}\text { Standardized } \\
\text { Coefficients }\end{array} \\
\text { Beta } \\
\end{array}$} & \multirow[t]{2}{*}{$\mathrm{T}$} & \multirow[t]{2}{*}{ Sig. } \\
\hline & & B & Std. Error & & & \\
\hline \multirow{4}{*}{1} & (Constant) & 5,433 & 10,8 & & 0,503 & 0,617 \\
\hline & Motivasi (p1) & 0,337 & 0,166 & 0,274 & 2,033 & 0,048 \\
\hline & Lingkungan Kerja Fisik (p4) & 0,493 & 0,22 & 0,326 & 2,237 & 0,030 \\
\hline & Kepuasan Kerja (p5) & 0,015 & 0,155 & 0,014 & 0,099 & 0,922 \\
\hline
\end{tabular}

Tabel 12. Hasil Uji T test Motivasi, Lingkungan Kerjka Fisik-Kepuasan Coefficients ${ }^{a}$

\begin{tabular}{|ll|r|r|r|r|r|}
\hline \multirow{2}{*}{ Model } & \multicolumn{2}{|c|}{$\begin{array}{c}\text { Unstandardized } \\
\text { Coefficients }\end{array}$} & $\begin{array}{c}\text { Standardized } \\
\text { Coefficients }\end{array}$ & \multirow{2}{*}{ T } & \multirow{2}{*}{ Sig. } \\
\cline { 2 - 4 } & \multicolumn{1}{|c|}{ B } & \multicolumn{1}{c|}{ Std. Error } & \multicolumn{1}{c|}{ Beta } & & \\
\hline \multirow{2}{*}{1} & (Constant) & 29,354 & 9,247 & & 3,174 & 0,003 \\
& Motivasi (p2) & $-0,058$ & 0,156 & $-0,052$ & $-0,37$ & 0,713 \\
& Lingkungan Kerja Fisik (p3) & 0,551 & 0,192 & 0,403 & 2,872 & 0,006 \\
\hline
\end{tabular}

a. Dependent Variable: Kepuasan Kerja 
Tabel 13. Hasil Uji Koefisien Determinasi Model Summary

\begin{tabular}{|c|c|c|c|c|}
\hline Model & $\mathrm{R}$ & $\mathrm{R}$ Square & Adjusted R Square & $\begin{array}{c}\text { Std. Error of the } \\
\text { Estimate }\end{array}$ \\
\hline 1 &, $487^{\mathrm{a}}$ & 0,237 & 0,188 & 4,706 \\
\hline
\end{tabular}

a. Predictors: (Constant), Kepuasan Kerja , Motivasi , Lingkungan Kerja Fisik

$$
\begin{aligned}
& e 2=\sqrt{1-\mathrm{r} 2} \\
& e 2=\sqrt{1-0,237} \\
& e 2=\mathbf{0 , 8 7 3}
\end{aligned}
$$

Tabel 14. Hasil Uji Koefisien Determinasi Model Summary

\begin{tabular}{|c|c|c|c|c|}
\hline Model & $\mathrm{R}$ & $\mathrm{R}$ Square & Adjusted R Square & $\begin{array}{c}\text { Std. Error of the } \\
\text { Estimate }\end{array}$ \\
\hline 1 &, $487^{\mathrm{a}}$ & 0,237 & 0,205 & 4,657 \\
\hline
\end{tabular}

a. Predictors: (Constant), Lingkungan Kerja Fisik, Motivasi

b. Dependent Variable : Kepuasan

$e 1=\sqrt{1-\mathrm{r} 2}$

$e 1=\sqrt{1-0,237}$

$e 1=\mathbf{0}, 873$

Berdasarkan gambar diatas dapat diketahui pengaruh langsung atau tidak langsung serta pengaruh lokal dari penelitian ini yaitu :

1) Pengaruh langsung motivasi terhadap kinerja (p1) $=\mathbf{0 , 3 3 7}$

2) Pengaruh tidak langsung motivasi terhadap kinerja p2 x p5 $=-0,058 \times 0,015=\mathbf{- 0 , 0 0 0 8 7}$

Maka pengaryh tidak langsung antara X1 ke Y sebesar - 0,00087

3) Pengaruh total motivasi terhadap kinerja

Pengaruh langsung + pengaruh tidak langsung

$=\mathrm{p} 1+(\mathrm{p} 2 \times \mathrm{p} 5)=0,337 \times-0,00087=\mathbf{- 0 , 0 0 0 2 9 3 1 9}$

4) Pengaruh total lingkungan kerja fisik terhadap kinerja

(p4) $=\mathbf{0 , 4 9 3}$

5) Pengaruh tidak langsung lingkungan kerja fisik terhadap kinerja p3 x p5 =0,551 x 0,015 = 0,008265

Maka pengaruh anatara X2 ke Y sebesar $\mathbf{0 , 0 0 8 2 6 5}$

6) Pengaruh total lingkungan kerja fisik terhadap kinerja

Pengaruh langsung + pengaruh tidak langsung

$=\mathrm{p} 4+(\mathrm{p} 3 \times \mathrm{p} 5)$

$=0,493+0,008265=\mathbf{0 , 5 0 1 2 6 5}$

Maka pengaruh total X2 ke Y sebesar 0,501265

Untuk mengetahui tingkat mediasi variabel kepuasan kerja terhadap kinerja dan komunikasi terhadap kinerja maka standar error dan koefisien indirect effect dapat dinyatakan :

1) $\mathrm{Sp} 2 \mathrm{Sp} 5=\sqrt{p 5^{2} s p 2^{2}+p 2^{2} s p 5^{2}+s p 2^{2} s p 5^{2}}$

Sp2Sp5 $=\sqrt{(0,015)^{2} \cdot(0,156)^{2}+(-0,058)^{2} \cdot(0,015)^{2}+(0,156)^{2} \cdot(0,155)^{2}}$

Sp2Sp5: $\sqrt{(0,000225) \cdot(0,024336)+(0,003364) \cdot(0,000225)+(0,024336) \cdot(0,024025)}$

Sp2Sp5 $=\sqrt{(0,000005475600)+(0.000000756900)+(0.000584672)}$

Sp2Sp5 $=\sqrt{0,000590904900}$

Sp2Sp5 = 0,024308535538 
2) $\operatorname{Sp} 3 \mathrm{Sp} 5=\sqrt{p 5^{2} s p 3^{2}+p 3^{2} s p 5^{2}+s p 3^{2} s p 5^{2}}$

Sp3Sp5 $=\sqrt{(0,015)^{2} \cdot(0,192)^{2} \cdot+(0,551)^{2} \cdot(0,155)^{2}+(0,192)^{2} \cdot(0,155)^{2}}$

Sp3Sp5: $\sqrt{(0,00225) \cdot(0,036864)+(0,303601) \cdot(0,024025)+(0,036864) \cdot(0,024025)}$

Sp3Sp5 $=\sqrt{0,000082944+0,007294014+0,000885658}$

Sp3Sp5 $=\sqrt{0,008262616}$

Sp3Sp5 = 0,090898931

Berdasarkan hal di atas maka dapat diperoleh nilai t statistis pengaruh mediasi sebagai berikut:

$$
\text { 1) } \begin{aligned}
\mathrm{t} 1 & =\underset{\mathrm{sp} 2 \mathrm{p} 5}{\mathrm{p} 5}=\frac{-0,058 \times 0,015}{0,156 \times 0,016}=-0,348557692=\mathbf{- 0 , 3 4 9} \\
\mathrm{t} 2 & =\underset{\mathrm{sp3p} 5}{\mathrm{p} 3 \mathrm{p} 5}=\frac{0,551 \times 0,015}{0,192 \times 0,015}=2,869791666=\mathbf{2 , 8 6 9}
\end{aligned}
$$

\section{Pembahasan Hasil Penelitian:}

Dengan melihat semua pengukuran diatas maka dapat ditarik kesimpulan sebagai berikut :

1) Karena thitung sebesar $-0,349$ dan $t$ tabel 2,008 dengan nilai signifikasi 0,05, maka dapat disimpulkan bahwa koefisien mediasi sebesar -0,00029319 signifikan yang berarti kepuasan tidak dapat menjadi mediator dalam pengaruh motivasi terhadap kinerja.

2) Karena t hitung sebesar 2,869 dan t tabel 2,008 dengan nilai signifikasi 0,05, maka dapat disimpulkan koefisien mediasi sebesar 0,501265 yang berarti kepuasan kerja dapat menjadi mediator dalam pengaruh lingkungan kerja fisik terhadap kinerja.

3) Hasil uji hipotesis 1 (Motivasi berpengaruh signifikan terrhadap kinerja) Motivasi mempunyai nilai t sebsar 2,033 dan nilai signifikansi 0,048 $<0,05$, hal ini berati bahwa nilai $2,033>2,008$ dan $0,048<0,05$ yang berati bahwa motivasi memiliki pengaruh yang positif dan signifikan terhadap kinerja. Hal ini sejalan dengan penelitian Bayu (2017), Aldo (2018), Edi (2016).

4) Hasil uji hipotesis 2 (Lingkungan Kerja Fisik berpengaruh signifikan terrhadap kinerja) Lingkungan Kerja Fisik mempunyai nilai t sebesar 2,237 dan nilai signifikansi yaitu 0,030 sehingga 2,237 $>2,008$ dan 0,030 $<0,05$ yang berarti bahwa Lingkungan Kerja Fisik memiliki pengaruh yang positif dan signifikan terhadap kinerja. Hal ini sejalan dengan penelitian Dasio (2017), I Putu Santikan (2020) dan Ida Bagsu (2018).

5) Hasil uji hipotesis 3 (Motivasi berpengaruh signifikan terrhadap Kepuasan kerja) Motivasi mempunyai nila t sebesar $\mathbf{- 0 , 3 7 0}$ dan nilai signifikansi 0,713 $>\mathbf{0 , 0 5}$, hal ini berati bahwa nilai $-\mathbf{0 , 3 7 0}<\mathbf{2 , 0 0 8}$ dan $\mathbf{0 , 7 1 3}>\mathbf{0 , 0 5}$ yang berati bahwa motivasi tidak memiliki pengaruh serta negative dan tida signifikan terhadap kepuasan kerja, hal ini tidak sejalan dengan penelitian Kadek (2015), Deyu (2013) Ian (2013).

6) Hasil uji hipotesis 4 (Lingkungan kerja fisik berpengaruh significant terhadap Kepuasan) Lingkungan Kerja Fisik mempunyai nila t sebesar 2,872 dan nilai signifikansi $0,006>0,05$, hal ini berati bahwa nilai 2,872 > 2,008 dan 0,006 >0,05 yang berati bahwa Lingkungan Kerja Fisik memiliki pengaruh yang positif dan signifikan terhadap kepuasan. Hal ini sejalan dengan penelitian Titi (2020), Herman (2020) dan Rasfiansi (2019).

7) Hasil Uji Hipotesis 5 (Kepuasan terhadap Kinerja) Kepuasan memiliki nilai 0,099 dan nilai signifikan 0,922 sehingga 0,099 $<2,008$ dan 0,922 >0,05 maka kepuasan tidak memiliki pengaruh dan tidak signifikan terhadap kinerja. Hal ini sejalan dengan penelitn Florida (2013), Desy (2013), Ayu (2013)

\section{Keterbatasan dan Agenda Penelitian Mendatang}

Yang menjadi keterbatasan dalam penelitian ini adalah ketika memperoleh data banyak responden yang mengisi kuisioner tidak langsung di isi, dikarenaka sebagaian karyawan mengisi kuisioner ketika jam istirahat atau jam pulang kerja, serta ruang lingkup penelitian yang diteliti hanya pada variabel motiasi, lingkungan kerja fisik, kinerja dan kepuasan jika digali lagi masih terdapat varibel lain yang mempengeruhi kinerja karyawan. 
Dari penelitian yang sudah dilakukan oleh penulis, diharapkan agar peneliti berikut nya bisa lebih memperluas varibel yang akan di teliti dan bisa menggunakan analis jalur dengan program Amos atau Smart Pls dan Lisrel.

\section{Kesimpulan dan Saran}

Berdasarkan hasil penelitian dan pembahasan yang telah dikemukan oleh penulis maka dapat ditarik kesimpulan sebagai berikut:

1) Dari hasil pengujian $t$ test menunjukan motivasi berpengaruh positif dan sigifikan terhadap kinerja.

2) Dari hasil pengujian t test menunjukan lingkungan kerja berpengaruh positif dan sigifikan terhadap kinerja.

3) Dari hasil pengujian t test menunjukan motivasi tidak berpengaruh positif dan tidak sigifikan terhadap kepuasan.

4) Dari hasil pengujian t test menunjukan lingkungan kerja fisik berpengaruh positif dan sigifikan terhadap kepuasan.

5) Dari hasil pengujian $t$ test menunjukan kepuasan tidak berpengaruh positif dan tidak sigifikan terhadap kinerja.

Berdasarkan hasil penelitian dan pembahasan yang telah dilakukan maka saran yang dapat diajukan sebagai berikut:

1) Perusahaan harus dapat meberikan kedudukan kepada karyawan berprestasi atau memberikan penghargaan berupa barang untuk karyawan yang berprestasi, agar karyawan dapat merasa dihargai baik dari dari kerja nya yang dilakukan selama ini..

2) Perusahaan memperbaiki sistemn pecahayaan di tempat bekerja, agar karyawan dapat bekerja dengan baik dan tenang seperti memberikan lampu tambhan atau jendela tambahan sehingga memudahkan cahaya matahari lebih masuk keruang kerja

3) Perusahaan meberikan kelonggaran waktu dalam menyelesaikan target pekerjaan kepada karyawan agar kualitas pekerjaan yang dihasilkan sesuai dengan yang diharapkan.

4) Perushaan membayara karyawan sesuai dengan beban kerjanya misanya sepereti ada lemburan maka lebih baik di hitung agar menambahkan gaji yang diperoleh karyawan.

\section{Daftar Pustaka}

A.A. Anwar Prabu. Mangkunegara. (2011). Manajemen Sumber Daya Manusia Perusahaan. Bandung: PT. Remaja Rosda. Karya.

A.A. Anwar Prabu Mangkunegara. (2013). Manajemen Sumber Daya Manusia Perusahaan. Bandung: Remaja Rosdakarya.

Arianto, N., \& Kurniawan, H. (2020). Pengaruh Motivasi dan Lingkungan Kerja Terhadap Kinerja Karyawan. JENIUS (Jurnal Ilmiah Manajemen Sumber Daya Manusia), 3(3), 312321. Link: http://openjournal.unpam.ac.id/index.php/ISDM/article/view/4869.

Arianto N. (2020). Kepemimpinan Dan Komunikasi Pengaruhnya Terhadap Kinerja Dengan Kepuasan Kerja Sebagai Variabel Intervening. Jurnal Kreatif Vol. 8 No 1 (2020). Link: http://openjournal.unpam.ac.id/index.php/kreatif/article/view/5719.

Arianto, N. (2019). Pengaruh Kepemimpinan Dan Motivasi Terhadap Kinerja Karyawan (Studi Pada Karyawan Direktorat Sumber Daya Di Sebuah Universitas Swasta Jakarta Barat). Jurnal Proceeding Universitas Pamulang. Vol. 1 No 1 (2019). Link: http://openjournal.unpam.ac.id/index.php/Proceedings/article/view/4247. 
Arianto, N. (2021). Pengaruh Komunikasi Dan Gaya Kepemimpinan Terhadap Kinerja Pada Karyawan Yayasan Aky Cireundeu. Jurnal Kreatif Vol 9, No 1 (2021). Link: http://www.openjournal.unpam.ac.id/index.php/kreatif/article/view/11170.

Arianto, N. (2018). Pengaruh Kepemimpinan Terhadap Kinerja dan Kepuasan Kerja Karyawan Pada PT. Gada Rajawali Dunia. Jurnal Jenius Vol. 1. No 2 (2018). Link: http://www.openjournal.unpam.ac.id/index.php/IJSDM/article/viewFile/1289/1025.

Edy Sutrisno. (2010). Manajemen Sumber Daya Manusia. Edisi Pertama. Cetakan Pertama. Jakarta : Penerbit Kencana.

Hasibuan, Malayu. (2016). Manajemen Sumber Daya Manusia. Jakarta: Penerbit Bumi Aksara.

J Winardi. (2013). Motivasi \& Pemotivasian Dalam Manajemen. Jakarta: PT Raja Grafindo Persada.

Laksmi Riani, Asri. (2013). Manajemen SDM Masa Kini. Yogyakarta : Graha Ilmu.

Luthans, Fred. (2011). Perilaku Organisasi. Yogayakarta : Andi.

Mangkunegara, A. P. (2012). Evaluasi Kinerja SDM. Bandung: Refika Aditama.

Sadili Samsudin. (2010). Manajemen Sumber Daya Manusia. Bandung : CV. Pustaka Setia.

Sedarmayanti. (2013). Manajemen Sumber Daya Manusia: Reformasi Birokrasi dan Manajemen Pegawai Negeri Sipil. Bandung: PT Refika Aditama.

Sugiyono. (2011). Metode Penelitian Kuantitaif Kualitatif dan R \& B. Bandung: Alfabeta.

Sugiyono. (2018). Metode Penelitian Kombinasi (Mixed Methods). Bandung: CV Alfabeta.

Wibowo. (2011). Manajemen Kinerja. Edisi Ketiga. Jakarta: PT Raja Grafindo Persada.

Wirawan. (2011). Evaluasi Teori Model Standar Aplikasi dan Profesi, Contoh Aplikasi Evaluasi Program: Pengembangan Sumber Daya Manusia, Program Nasional Pemberdayaan Masyarakat (PNPM) Mandiri Pedesaan, Kurikulum, Perpustakaan, dan Buku Tes. Jakarta: Raja Grafindo Persada. 